\title{
Operating performance of SMEs in Thailand after going public
}

\author{
Marisa LAOKULRACH \\ International College, \\ National Institute of Development Administration, Thailand \\ marisa.laokulrach@gmail.com,marisa.lao@nida.ac.th
}

\begin{abstract}
This study investigates the operating performance of small and medium enterprises (SMEs) in Thailand, in terms of efficiency and profitability, after issuing initial public offering (IPO) in comparison to their pre-IPO performance. A cross-sectional analysis is also applied to examine the impact of ownership retention and underpricing on operating performance using different measurements. Studies in most developed countries identify a deterioration in post-IPO operating performance; however, few studies have been conducted in emerging markets, especially on SMEs performance after IPO issuance for fund raising. The results of 82 Thai SMEs listed in the Market for Alternative Investment (MAI) during 2001-2014 show the decline of the operating performance for post-IPO issuance compared to a year prior IPO whic99h are consistent with the "window dressing" and "market timing" concepts. SMEs improve their revenue significantly after going public even though their growth is lower than the assets' growth rate. The original ownership retention has no significant impact on the operating performances in different measurements which are inconsistent with previous studies. The original owners of SMEs maintain relatively high managerial ownership after going public thus there is less agency cost problem. Underpricing has a negative impact on the changes in sales for post-IPO relative to pre-IPO, reflecting that the expectations of investors toward companies' revenues are different from reality. The findings benefit company owners and management in the area of performance sustainability, and regulators in terms of auditing companies' performances prior to going public.
\end{abstract}

Keywords: Operating Performance; Initial Public Offering; Ownership Retention; SMEs

Please cite the article as follows: Laokulrach, M. (2019), "Operating Performance of SMEs in Thailand after Going Public", Management \& Marketing. Challenges for the Knowledge Society, Vol. 14, No. 1, pp. 1-13. DOI: 10.2478/mmcks-2019-0001.

\section{Introduction}

Initial public offering (IPO) is one of the most important tools for companies to raise capital funds for business expansion, as well as to change their status to that of a public company limited. This transformation also increases the prestige of a company from the investor's point of view. Being listed on the capital market requires compliance with rules and regulations, for instance good governance or transparency, so investors would expect a public company limited to have better operating performances, but results from many studies identify contrary results.

Results from the majority of previous studies in emerged and emerging market economies explain the decline in the operating performances of companies after going public by referring to three main concepts. First, agency problem, as identified by Jensen and Mecking (1976), is the reduction in management ownership in a company after going public. The second concept is the "window dressing" of a company's financial statements prior to going public, while the third is the issuance of IPOs during a period of good performance, which is known as "market timing". 
The Thai government has been supporting the operations of small and mediumenterprises (SMEs) during the last decade. The overall gross domestic product (GDP) of SMEs is approximately $42 \%$ of the country's GDP in 2016. The master plan of Thai SMEs is to promote SMEs to generate 50\% of GDP by 2020 (OSMEP, 2016). The development of SMEs is also expected to result in wider income distribution and inequality reduction. In addition, government policies are implemented to support SMEs in ways to help increase the opportunities and competitiveness in the region and the global marketplace. One of the strategic plans is to ease access to sources of funds.

Since the Asian financial crisis in 1997, the equity market in Thailand has become an important source of funds for private companies. The Stock Exchange of Thailand (SET) is a mainboard equity market and is considered a growing capital market in emerging markets. In 2013 and 2014, the market capitalization of IPOs on the SET reached the highest in the ASEAN region (SET, 2014).

Apart from the SET, Thailand also has the Market for Alternative Investment (MAI) as the capital market for mainly young, high-growth, innovative, and knowledge-based SMEs. The MAI was established under The Securities Exchange of Thailand Act and officially commenced operations on June 21,1999 . The MAI's objective is to create new fund-raising opportunities for innovative businesses with high potential growth, as well as to provide a wider range of investment alternatives for investors. The missions of the MAI are to 1) provide opportunities for entrepreneurs and SMEs access to funds, 2) pursue transparency and good governance for sustainable growth, and 3) strengthen competitiveness (SET, 2017). Increasing numbers of SMEs have listed on the MAI over the past 10 years.

Listing on the equity market is not only about raising funds but it also serves as a channel for companies to increase their trustworthiness in the eyes of investors. Companies may expand their business further with seasoned equity offering (SEO) issues, thus performance management of companies after going public is important.

There are very few studies of post-IPO operating performance of SMEs in Thailand. The study of IPO companies on the SET by Kim, Kitsabunnarat, and Nofsinger (2004) suggests a decline in performance as a post-IPO issue, as well as the negative relationship of intermediate ownership retention and performance. The current study aims to explore the operating performance of 82 SMEs in Thailand after becoming public company limited on the MAI during 2001-2014. The determinants of performance used include ownership retention and underpricing with the control variables including company age (before IPO), size of company, and market capitalization of IPO. The purpose of the study is to investigate whether the results of post-IPO performances of SMEs are consistent with the IPOs in the mainboard market and results from previous studies.

\section{Literature review}

Results from previous studies conducted in different countries use three main points to explain the decline in companies' operating performances after going public. First, according to the agency problem, agency costs occur when there is a reduction in management ownership in a company after going public (Jensen and Mecking, 1976). Conflicts of interest may occur between managers and shareholders due to the decline of entrepreneurial ownership interests. Managers may use the raising funds in nonvalue maximizing projects to receive incentives from perquisite consumption (Jain and Kini, 
1994). Agency costs can be observed in the form of reduction in profitability, decline in operational efficiency, as well as decline in company value (McConaughy, Dhatt, and Kim 1996).

On the other hand, becoming a public company enables companies to utilize external monitoring. Managers are forced to drive the business in a competitive labor market, and their decisions are then assessed by the market. Shareholders can design compensation packages, such as stock options or stock-price indexed payments, for the managers. Thus, improvements in post-issue performance is expected (Xie, 2010).

Second, "window dressing" which is the earning management to maintain the attractive accounting statements at the pre-IPO stage to facilitate fundraising, is common practice. In many cases, however, companies are not able to maintain a good performance after being listed (Arik and Mutlu, 2015). Public companies and IPO are overvalued by investors from high earnings reports (Ahmad-Zaluki, 2008).

The third explanation is the issuance of IPO during periods of good performance, which is called "market timing" or "window of opportunity". Companies issue IPOs to raise equity funding during high performance or good economic stages. Companies can take advantage of bull markets and issue IPO during periods with high market-to-book ratio. However, companies cannot maintain their performances after going public (Jain and Kini, 1994; Xie, 2010).

Post-IPO performance has been a widely studied topic in various countries. Jain and Kini (1994) examined a decline in companies' operating performances after the IPO measured using operating returns on assets and operating cash flows deflated by assets, as well as industry adjustments. But IPO companies have high growth in sales and capital expenditures compared to equivalent companies in the same industry in post-IPO periods. Thus, the decline in operating performance is not caused by lack in sales growth opportunities or cutback of capital expenditures. Also, companies with high retention rate of entrepreneurial ownership have superior performance compared to other companies. There is no relationship between post-IPO operating performance and initial returns of IPO.

The study of Xie (2010) on the US property-liability insurance companies' postIPO performance shows no experience of post-issue underperformance in efficiency, returns on assets, or stock returns. They have improvement in allocative efficiency and cost efficiency.

The study of the Borsa Istanbul market by Arik and Mutlu (2015) identifies the decline in operating performance indicators by operating return on assets, EBITDA to assets, and asset turnovers for each of the three years after IPO relative to the pre-IPO period. Kutsuna, Okamura, and Cowling (2002) studied the pre- and post-IPOs in JASDAQ of Japan. The study found that JASDAQ companies have sharp decrease in sales, ordinary profits, and net profits growth after flotation. Ownership retention is closely related to post-IPO operating performance. Companies in which the top shareholders have decreased ownership stakes after IPO showed poorer performance. Post-IPO deterioration in operating performance is partly caused by the reduced managerial ownership. Operating performance after IPO is significantly and positively related to market capitalization and negatively related to company's age and number of employees. 
In 2008, Ahmed-Zulaki investigated the post-IPO performance of companies in Malaysia and confirmed the long-term underperformance of IPOs, as well as the effects of earnings manipulation at the time of the listing process on IPOs. The IPOs of stateowned enterprises on the Shanghai Stock Exchange and the Shenzhen Stock Exchange in China during 1996-1997 were studied by Chi and Oadgett (2006). The results show a significant reduction in profitability, sales growth rates, and also efficiency, but significant increase in sales. Anderson, Chi, and Wang (2015) identified the underperformance of the ChiNext IPOs as well as the significant deterioration of operating performance after listing.

The study of IPO companies on the SET by Kim et al. (2004) reveals a higher magnitude in deterioration of operating performance for post-IPO when compared to the United States. A nonlinear relationship is found between ownership retention and operating performance. Companies with intermediate levels of managerial ownership are found to perform worse after going public.

Limpaphayom and Ngamwutikul (2004) studied companies' performance for post-issue of seasoned equity offering (SEO) on the SET and the findings confirm that the performance increases in the year prior to the SEO issuing then later declines during the post-issue period.

The current research raises the question of whether the decline in operating performance subsequent to the IPO process of SMEs can be observed occurring in Thailand. Another question is whether the ownership retention after IPO and underpricing of company's stocks influence post-IPO performances.

According to the agency cost theory, window dressing, market timing concept, and the results of most previous studies, this study hypothesizes that the long-term post-IPO operating performance declines compared to pre-IPO performance.

Ownership retention is expected to positively affect post-IPO performance. A company with a higher ownership retention rate after IPO should have a superior operating performance relative to one with a lower retention rate (Jansen and Meckling, 1976).

Underpricing of company's stocks is hypothesized to have a positive impact on the post-IPO operating performance. Signaling model from Allen and Faulhaber (1989) state that "high-quality" companies tend to underprice their IPOs to distinguish themselves from "low-quality" companies and later receive the benefit from SEO. Companies may underprice their IPO stocks to signal high quality to investors, then they should show better post-IPO operating performance than other companies with no underpricing (Jain and Kini, 1994).

\section{Methodology \\ Data Collection}

Data are collected and gathered from different sources. The list of IPO in the MAI is acquired from the SET website. The pre-IPO data are collected from the prospectuses filed with the Security and Exchange Commission (SEC) of Thailand. The pre-IPO data include the operating performance, asset size, offer price, company age, and ownership structure. The post-IPO data are collected from the Thomson Reuter Datastream. The data include operating performance, first trading day price, and market capitalization. 
The MAI has been officially trading stocks since 2001. There are 90 IPO companies on the MAI from 2001 to 2014 found to be in eight industries, namely agro \& food, consumer products, financials, industrials, property \& construction, resources, services, and technology. Since the post operating performances in a 3-year period is needed for the study, the data of IPO companies only until 2014 are used. Only 82 companies completed information on the required variables and are applicable in this study. The distribution of IPO companies in each year and in different industries is shown in Table 1.

Table 1. Distribution of IPO Companies in the MAI during 2001-2014

\begin{tabular}{|c|c|l|c|}
\hline Year & $\begin{array}{c}\text { Number } \\
\text { of IPO } \\
\text { company }\end{array}$ & \multicolumn{1}{|c|}{ Industry } & $\begin{array}{l}\text { \% of } \\
\text { Sample }\end{array}$ \\
\hline 2001 & 1 & Financials (1) & $1.22 \%$ \\
\hline 2002 & 2 & Industrials (1), Services (1) & $2.44 \%$ \\
\hline 2003 & 3 & Industrials (1), Services (1), Technology (1) & $3.66 \%$ \\
\hline 2004 & 9 & $\begin{array}{l}\text { Industrials (4), Property \& Construction (1), Services (3), } \\
\text { Resources (1) }\end{array}$ & $10.98 \%$ \\
\hline 2005 & 8 & $\begin{array}{l}\text { Industrials (4), Property \& Construction (1), Services (1), } \\
\text { Agro \& Food (1), Financial (1) }\end{array}$ & $9.76 \%$ \\
\hline 2006 & 2 & Industrials (1), Resources (1) & $2.44 \%$ \\
\hline 2007 & 4 & Industrials (2), Technology (1), Consumer Products (1) & $4.88 \%$ \\
\hline 2008 & 2 & Property \& Construction (2) & $2.44 \%$ \\
\hline 2009 & 6 & $\begin{array}{l}\text { Property\& Construction (1), Services (2), Consumer Products (2), } \\
\text { Resources (1) }\end{array}$ & $7.32 \%$ \\
\hline 2010 & 5 & Industrials (2), Services (3) & $6.10 \%$ \\
\hline 2011 & 4 & Industrials (2), Property \& Construction (1), Resources (1), & $4.88 \%$ \\
\hline 2012 & 8 & $\begin{array}{l}\text { Property \& Construction (2), Services (2), Agro \& Food (1), } \\
\text { Industrials (3) }\end{array}$ & $9.76 \%$ \\
\hline 2013 & 12 & $\begin{array}{l}\text { Property \& Construction (1), Services (4), Technology (1), } \\
\text { Resources (1), Industrials (2), Consumer Products (2), Financials } \\
\text { (1) }\end{array}$ & $14.63 \%$ \\
\hline 2014 & 16 & $\begin{array}{l}\text { Property \& Construction (1), Services (5), Resources (4), } \\
\text { Industrials (3), Agro \& Food (1), Financials (2) }\end{array}$ & $19.51 \%$ \\
\hline Total & 82 & & $100 \%$ \\
\hline
\end{tabular}

Source: Thomson Reuter Database and MAI

High number of IPOs were found in the years 2004 and 2005, which declined during 2008 to 2011 due to the world economic crisis. The number of IPO companies increased from 2012 to 2014 . The MAI has become an important alternative source of funds for SMEs in Thailand. The highest proportion of IPO companies are found to be in the industrials and services industry, consisting of 27 and 26 companies, respectively. The lowest proportion of three companies are in the technology industry.

\section{Pre- and Post-Operating Performance}

Operating performances are measured by four ratios at the end of fiscal year. The first measurement is operating return on assets which is the ratio of operating profit divided by total assets (EBIT/TA). Second ratio is total asset turnover (TATO) equals to sales over the total assets. Third measurement is operating cash flows on assets which equals the 
cash flows from the operating activities divided by total assets (CF/TA). The last measurement in the net profit margin is net profits divided by sales (NPM). The first and second ratios measure asset efficiency and utilization. The cash flow to total asset ratio is used as the operating cash flow is often used in Net Present Value (NPV) measurement in company and project evaluation of a company. The last ratio examines the profitability of a company. The 7-year period operating performance used in the study included 3 years of pre-IPO (year -3, -2, and -1), year of the IPO (year 0), and 3 years of post-IPO.

The change in the operating performance ${ }_{i}(\mathrm{t})$ between the post-IPO and pre-IPO is examined, where i represents the company, and t represents year of post-IPO related to pre-IPO. The operating performance data is skewed, not normally distributed, and the mean is sensitive to outliers. Hence, the median is used to measure the central tendency value.

The methods of Jain and Kini (1994) and Kim et al. (2002) are applied in this study. The change in operating performance over time after going public in relation to year prior to IPO is examined by median difference.

Median value of [operating performance $i, t$ - operating performance of ${ }_{i,-1}$ ]

Where i represents a company

t represents a fiscal year end after IPO

The median change of operating performance during each of the 3 years after the IPO $(t=+1,+2,+3)$ relative to operating performance of one year prior the IPO $(t=-1)$ is identified and reported. The significant change is tested using the Wilcoxon signed rank test. The change in level of ratio of post-IPO compared to pre-IPO identifies the improvement in operating performance of a company.

The industry-adjusted performance of an IPO is measured by using the difference between the change in a company's performance and the median change of matching companies' operating performance in the same industry. The eight industries classification by MAI is applied in the analysis.

\section{Regression Analysis}

The multiple regression analysis is used to test the determinants of the change in operating performance. Referring to the agency theory by Jensen and Mecking (1976), it was expected that companies with higher ownership retention to have superior operating performance.

Companies may signal their quality to the market by underpricing their stocks. Assuming information asymmetry between issuers and investors, studies by Allen and Faulhaber (1989) explains that high quality companies sell a small proportion of the company's shares on the IPO and also underprice their stocks. Then, a SEO would be made when information asymmetry is removed, and market prices are established. Low value companies trying to underprice themselves would suffer from the SEO when their true quality is revealed. Thus, signaling theory predicts that underpriced companies should exhibit superior performance over those that are not underpriced. 
This study tests the impact of ownership retention after IPO issuance and underpricing on post-IPO operating performance, with the use of control variable factors being company age, company size, and market capitalization on the IPO.

The following model is tested:

Change in performance $\mathrm{i}(\mathrm{t})=\alpha+\beta_{1}$ Owner $+\beta_{2}$ Age $+\beta_{3}$ Size $+\beta_{4}$ Mcap $+\beta_{5}$ Under where:

Change in performance ${ }_{i(t)}$ is change in EBIT/TA, CF/TA, TATO, sale growth, and NPM of year +1 relative to -1 .

Owner is the percentage of the original owner (pre-IPO) retention after going public.

Age is the difference between a company's established year and IPO year.

Size is Ln of company's assets in year -1.

Mcap is the market capitalization on IPO issue.

Under is the initial return on the first trading day relative to the offer price.

\section{Empirical Findings}

This section identifies the empirical results of the study. Table 2 shows the characteristics of IPO companies using the average statistic of mean and median. The results of pre- and post-operating performance and regression analysis are also presented.

Table 2. Descriptive Data of IPO Companies

\begin{tabular}{|l|c|c|}
\hline \multicolumn{1}{|c|}{ Characteristic } & Mean & Median \\
\hline Initial returns (\%) & 16.95 & 9.56 \\
\hline Offer price (Baht per share) & 3.79 & 2.73 \\
\hline Alpha (\%) & 76.33 & 76.21 \\
\hline Size of issue (million baht) & $1,863.68$ & 774.06 \\
\hline Established year to IPO (years) & 16.24 & 15.00 \\
\hline \multicolumn{2}{|c|}{ Source: Authors' own research results }
\end{tabular}

The median of the initial returns on the first trading day price relative to the offer price of all companies is at $9.56 \%$ which confirms the underpricing of IPO shares. The average of the offer price is at 3.79 baht per share with a median of 774.06 million baht of market capitalization on IPO date as they are SME companies thus the price per share is not high. The original owners (pre-IPO) maintain $76.21 \%$ of the total shares after listing on the MAI, thus SMEs in Thailand are managed and controlled mainly by the original owners after IPO issuance. Most companies have been established approximately 15 years before going public. 
Table 3. Operating Performance of Pre- and Post-IPO companies

\begin{tabular}{|c|c|c|c|c|c|c|c|}
\hline & -3 & -2 & -1 & $\mathbf{0}$ & +1 & +2 & +3 \\
\hline \multicolumn{8}{|c|}{ Sales (million baht) } \\
\hline \multirow{2}{*}{$\begin{array}{l}\text { Mean } \\
\text { Median }\end{array}$} & 477.46 & 587.16 & 687.13 & 840.00 & 939.22 & 1023.62 & 1150.34 \\
\hline & 373.57 & 430.56 & 500.46 & 657.04 & 701.17 & 743.49 & 804.98 \\
\hline \multicolumn{8}{|l|}{ EBIT/TA } \\
\hline \multirow{2}{*}{$\begin{array}{l}\text { Mean } \\
\text { Median }\end{array}$} & $14.07 \%$ & $14.34 \%$ & $15.66 \%$ & $10.53 \%$ & $8.45 \%$ & $7.53 \%$ & $2.39 \%$ \\
\hline & $10.15 \%$ & $11.19 \%$ & $12.32 \%$ & $8.67 \%$ & $8.36 \%$ & $6.07 \%$ & $3.82 \%$ \\
\hline \multicolumn{8}{|l|}{ CF/TA } \\
\hline \multirow{2}{*}{$\begin{array}{l}\text { Mean } \\
\text { Median }\end{array}$} & $9.01 \%$ & $2.08 \%$ & $10.53 \%$ & $5.57 \%$ & $4.00 \%$ & $6.40 \%$ & $7.80 \%$ \\
\hline & $9.01 \%$ & $6.91 \%$ & $10.97 \%$ & $6.01 \%$ & $5.57 \%$ & $7.32 \%$ & $5.77 \%$ \\
\hline \multicolumn{8}{|l|}{ Sales/TA } \\
\hline \multirow{2}{*}{$\begin{array}{l}\text { Mean } \\
\text { Median }\end{array}$} & 1.74 & 1.64 & 1.59 & 1.20 & 1.18 & 1.07 & 1.10 \\
\hline & 1.31 & 1.33 & 1.32 & 1.14 & 1.17 & 1.07 & 1.05 \\
\hline \multicolumn{8}{|l|}{ NPM } \\
\hline \multirow{2}{*}{$\begin{array}{l}\text { Mean } \\
\text { Median }\end{array}$} & $3.62 \%$ & $6.12 \%$ & $7.37 \%$ & $9.96 \%$ & $9.90 \%$ & $8.41 \%$ & $6.60 \%$ \\
\hline & $3.37 \%$ & $5.01 \%$ & $6.49 \%$ & $6.69 \%$ & $7.16 \%$ & $5.88 \%$ & $5.08 \%$ \\
\hline Sample size & 82 & 82 & 82 & 82 & 82 & 82 & 82 \\
\hline
\end{tabular}

The sales of companies increase during a 7-year period of pre- and post-IPO, especially after listing. As shown in Table 3, the median of sales is 657.04 million baht on the IPO year and 804.98 million baht in year 3 after IPO. The operating performance of EBIT/TA increases from year -3 to year -1 , then declines from year of the IP0 to year +3 . Operating cash flows to assets also increases in year -3 to -1 and declines in year 0 and +1 . Total asset turnover declines from year -3 to year +3 . Profitability increases from three years before listing until two years after listing then declines in year +3 .

Table 4. Post-IPO Companies' Operating Performance

\begin{tabular}{|l|c|c|c|c|}
\hline & $\begin{array}{c}\text { From } \\
\mathbf{- 1} \text { to 0 }\end{array}$ & $\begin{array}{c}\text { From } \\
\mathbf{- 1} \text { to +1 }\end{array}$ & $\begin{array}{c}\text { From } \\
\mathbf{- 1} \text { to +2 }\end{array}$ & $\begin{array}{c}\text { From } \\
\mathbf{- 1} \text { to +3 }\end{array}$ \\
\hline EBIT/TA & & & & \\
$\quad$ Median percentage change (\%) & $-31.00^{* * *}$ & $-32.31^{* * *}$ & $-52.03^{* * *}$ & $-68.83^{* * *}$ \\
$\quad$ Median industry-adjusted change (\%) & $-10.06^{* * *}$ & $-15.00^{* * *}$ & $-20.12^{* *}$ & -35.03 \\
\hline CF/TA & & & & \\
$\quad$ Median percentage change (\%) & $-4.28^{* *}$ & $-4.50^{* *}$ & -2.69 & -4.76 \\
$\quad$ Median industry-adjusted change (\%) & $-1.00^{* *}$ & $-3.67^{*}$ & -1.00 & -4.67 \\
\hline Sales & & & & \\
$\quad$ Median percentage change (\%) & $31.29^{* * *}$ & $40.10^{* * *}$ & $48.61^{* * *}$ & $60.85^{* * *}$ \\
$\quad$ Median industry-adjusted change (\%) & $24.57^{* * *}$ & $34.92^{* *}$ & $58.35^{*}$ & 81.23 \\
\hline NPM & & & & \\
$\quad$ Median percentage change (\%) & 2.31 & 9.09 & -9.55 & $-22.19^{*}$ \\
$\quad$ Median industry-adjusted change (\%) & $4.00^{* *}$ & 2.00 & 0.00 & -16.25 \\
\hline TATO & & & & \\
$\quad$ Median percentage change (\%) & $-12.98^{* * *}$ & $-15.00^{* * *}$ & $-18.94^{* * *}$ & $-20.35^{* *}$ \\
Median industry-adjusted change (\%) & $-32.77^{* *}$ & $-13.34^{* * *}$ & -10.89 & $-11.54^{*}$ \\
\hline
\end{tabular}

${ }^{*}$ Statistically significant at $10 \%$ level

Source: Authors' own research results

** Statistically significant at $5 \%$ level

${ }^{* * *}$ Statistically significant at $1 \%$ level 
Table 4 shows the operating performance of IPO companies from year $0,+1,+2$, and +3 , respectively, relative to a year prior to the IPO. The EBIT/TA declines significantly at $1 \%$ level from year of the IPO until year +3 compared to a year prior to IPO with a median percentage change from $-30 \%$ to approximately $-68 \%$. Also, after industry adjustment, EBIT/TA shows a deterioration in performance in year 0 and year +1 relative to year -1 at $1 \%$ significance level and at $5 \%$ significance for year +2 in comparison to year -1's performance. The level of median change in EBIT/TA are similar to the study of IPO on the SET by Kim et al. (2004). However, they were nearly 8 to 9 times larger than those of Jain and Kini's (1994) study on the USA. Thus, this study confirms the asymmetric information as well as the window dressing issue in both the main equity market (SET) and the alternative market for SMEs (MAI) in Thailand as an emerging market.

Regarding the operating cash flow to total assets, the post-IPO performance of years 0 and +1 relative to year -1 is seen to decline significantly at $5 \%$ level with a median percentage change of $-4.28 \%$ and $-4.50 \%$, respectively. The same results are found after industry adjustment.

The sales of companies increased significantly at $1 \%$ level from year $0,+1,+2$, and +3 consecutively compared to a year prior the listing, with consistent results found after industry adjustment. These results are different from the JASDAQ IPO (Kutsuna et al., 2002) but consistent with the study of the SET (Kim et al., 2004), and as well as the one in the USA (Jain and Kini, 1994).

The median percentage change of profitability has increased from year 0 and year +1 relative to year -1 , although at an insignificant level, then later significantly declines in year +3 at $1 \%$ level. These results imply that companies can generate significantly higher sales after listing but not higher profits due to the higher growth in expenses. These again emphasize the possibility of owners and underwriters in attempting to window dress the performances of companies prior to going public. The companies may also issue the IPO during a period of economic high performance or when the company itself is performing well in order to take the "window of opportunity" to sell shares to the public easily. The results are similar to the study of Kutsuna et al. (2002) of JASDAQ in Japan in terms of the decline in NPM for post-issue.

The asset turnover of companies after going public decreases significantly at $1 \%$ level in years $0,+1,+2$ relative to year -1 with a percentage change with a median of $12.98 \%,-15 \%$, and $-18.94 \%$, respectively, and significantly at $5 \%$ level in year +3 compared to year -1 with a percentage change with a median of $-20.35 \%$. The statistically significant increase in sales, together with the decrease in asset efficiency, explain that companies raise funds from the equity market and invest in their assets to generate higher revenues. The growth in assets is at a higher rate than the increase in revenues.

In summary, the evidence shows that IPO companies exhibit post-IPO inferior operating performance relative to the year prior to going public. Next, the study of different factors affecting operating performances are examined. Multiple regression analysis is applied in the study. The correlation between each pair of variables is shown in Table 5. 
Table 5. Correlation Matrix

\begin{tabular}{|c|c|c|c|c|c|c|c|c|c|}
\hline & Underpricing & \begin{tabular}{c|} 
Market \\
Capitalization
\end{tabular} & $\begin{array}{c}\text { Firm } \\
\text { Size }\end{array}$ & $\begin{array}{c}\text { Firm } \\
\text { Age }\end{array}$ & TATO & Sale & $\begin{array}{c}\text { Owner } \\
\text { Retention }\end{array}$ & $\begin{array}{c}\text { EBIT/ } \\
\text { TA }\end{array}$ & CF/TA \\
\hline Underpricing & 1.000 & 0.558 & 0.098 & 0.121 & 0.074 & $\begin{array}{c}- \\
0.218 \\
\end{array}$ & -0.007 & 0.030 & 0.035 \\
\hline $\begin{array}{l}\text { Market } \\
\text { Capitalization }\end{array}$ & & 1.000 & 0.582 & 0.105 & 0.092 & 0.151 & 0.159 & 0.103 & 0.000 \\
\hline Firm Size & & & 1.000 & 0.141 & 0.432 & 0.230 & 0.214 & 0.481 & 0.243 \\
\hline Firm Age & & & & 1.000 & 0.115 & $\begin{array}{c}- \\
0.003 \\
\end{array}$ & -0.012 & 0.167 & 0.045 \\
\hline TATO & & & & & 1.000 & 0.154 & 0.030 & 0.419 & 0.107 \\
\hline Sale & & & & & & 1.000 & -0.085 & $\begin{array}{c}- \\
0.013 \\
\end{array}$ & -0.175 \\
\hline $\begin{array}{l}\text { Ownership } \\
\text { Retention }\end{array}$ & & & & & & & 1.000 & $\begin{array}{c}- \\
0.015 \\
\end{array}$ & 0.044 \\
\hline EBIT/TA & & & & & & & & 1.000 & 0.519 \\
\hline $\mathrm{CF} / \mathrm{TA}$ & & & & & & & & & 1.000 \\
\hline
\end{tabular}

Source: Authors' own research result

From the correlation matrix, underpricing has a weak negative relationship with sales and owner retention. Sales also has a negative relationship with firm age, ownership retention and also with operating performance of EBIT/TA and CF/TA. Firm age has a very weak negative relationship with ownership retention and sales. Ownership retention also relates to EBIT/TA negatively. The other pair of variables relate with each other positively. None of the variables have a strong negative relationship with correlation of less than -0.75 or a strong positive relationship with correlation of more than 0.75 with each other, therefore the multiple regression model can be used for testing in this study.

Table 6. Cross Sectional Analysis of Post-IPOs' Operating Performance of Year -1 to Year +1

\begin{tabular}{|l|l|l|l|l|c|}
\hline \multirow{2}{*}{$\begin{array}{c}\text { Independent } \\
\text { Variables }\end{array}$} & \multicolumn{5}{|c|}{ Dependent Variables } \\
\cline { 2 - 6 } & EBIT/TA & CF/TA & TATO & Sale & NPM \\
\hline Intercept & $-4.051^{* * *}$ & $-2.193^{* *}$ & $-3.610^{* * *}$ & -4.660 & -0.220 \\
\hline OWNER & -1.189 & 0.146 & -0.508 & -1.607 & -0.133 \\
\hline AGE & 0.967 & 0.068 & 0.249 & -0.172 & 0.674 \\
\hline UNDER & 1.436 & 1.517 & 1.806 & $-3.401^{* * *}$ & -0.677 \\
\hline Ln(ASST) & $5.918^{* * *}$ & $3.197^{* *}$ & $5.101^{* * *}$ & $2.364^{*}$ & 1.042 \\
\hline Ln(MCAP) & $-2.756^{* * *}$ & $-2.323^{* *}$ & $-2.709^{* * *}$ & $2.430^{* *}$ & -0.254 \\
\hline $\begin{array}{l}\text { Adjusted R } \\
\text { Square }\end{array}$ & 0.288 & 0.064 & 0.210 & 0.141 & -0.015 \\
\hline F-Statistic & $7.956^{* * *}$ & $2.178^{*}$ & $5.572^{* * *}$ & $3.825^{* * *}$ & 0.756 \\
\hline Durbin Watson & 1.535 & 1.971 & 2.178 & 2.280 & 1.999 \\
\hline
\end{tabular}

* $10 \%$ significant level

Source: Authors' own research results

** $5 \%$ significant level

*** $1 \%$ significant level 
The dependent variable is the difference in operating performance of EBIT/TA, $\mathrm{CF} / \mathrm{TA}$, TATO, sales, and NPM of year +1 relative to year -1 . Ownership retention insignificantly affects change in EBIT/TA, TATO, and NPM negatively, while positively affecting CF/TA. The results are inconsistent with the study of Jain and Kini (1994), Kutsuna et al. (2002), and also Kim et al. (2004) which identified the significant impact of ownership retention to the change in operating performances. The original owners of SMEs tend to retain a high percentage of managerial ownership for post-IPO so the agency cost problem may occur less in the MAI market than to the SET (main equity market) in Thailand. The original owners still control the managerial rights and activities.

Underpricing of the IPO has insignificantly positive impact on the change in EBIT/TA, CF/TA, TATO, and NPM. These results are consistent to the study by Jain and Kini (1994) who found no significant relationship between operating performance and underpricing. The interesting difference in results from Jain and Kini is explained as change in sales after IPO. The underpricing of IPO shares has a negative impact on the change in sales at $1 \%$ significance level. The more underpriced companies are found to gain higher expectations from investors as a good firm to generate higher revenues, but the reality is different.

The change in EBIT/TA, CF/TA, TATO, and sales are positively significantly affected by size of firm, so the larger companies have better ability to generate operating performance after listing. The market capitalization on the IPO date significantly negatively affects the EBIT/TA, CF/TA, and TATO, and positively affects the sales growth after IPO. Company age has no significant impact on operating performance, which is similar to the studies of JASDAQ and SET. All variables have insignificant impact on the change of net profit margin.

\section{Conclusion}

This study examines the post-IPO operating performance of 82 SMEs that list their firm on the MAI, Thailand. The empirical result shows a substantial decline in post-issue operating performance during the three years after the market relative to pre-IPO levels using several measurements. The hypothesis of declining operating performance after going public is accepted. The results are similar to the studies' results in most emerged countries. Although companies can increase their sales growth level after IPO, the preIPO operating performance cannot be sustained. This is also evidence of the window dressing of financial statements for earnings management that occurs during the listing process, and also of market timing during the issuing. Confirming the study of Kim et al. (2004), the deterioration of operating return on assets in Thailand is more than found in the United States. This may be evidence of a higher level of information asymmetry between owners and investors in the emerging market.

A cross-sectional analysis is applied to identify the result of ownership retention and underpricing to post-IPO operating performance. The expected positive relationship of the owner retention rate with the post-IPO performance is declined. The pre-IPO original owners of SMEs in Thailand maintain a relatively high ownership percentage after IPO so there is no significant impact of this factor on post-IPO operating performance. This reveals less agency cost problems in the MAI when compared to the SET in Thailand. 
Underpricing has no impact on operating performance while it has a negative significant impact on sales growth after IPO-issue. Investors have higher expectations on highly underpriced companies, but in reality, they cannot have a higher post-IPO performance than less underpriced companies. The signaling theory cannot be supported in the Market for Alternative Investment in Thailand.

The author intends for this study's results to benefit SMEs who are currently considering being listed on the equity market. The evidence of higher ability to generate asset levels and sales should encourage companies to raise their equity funding but should also be aware of the window dressing issue, and signaling via underpricing. The sustainability of their post-issue performance benefits them in terms of the seasoned equity offerings in the future. The regulator of the equity market should also design regulations and mechanisms to promote good governance and market discipline. For future studies, other variables such as the economic situation during IPO, multi-country study, and a longer time span after IPO should be explored.

\section{References}

Ahmad-Zaluki, A.N., (2008), “Post-IPO Operating Performance and Earning Management", International Business Research, 1(2), pp. 39-48

Allen, F., Faulhaber, G., (1989), "Signalling by underpricing in the IPO market", Journal of Financial Economics., 23 (2), pp. 303-323

Anderson, H., Chi, J., and Wang. Q., (2015), "IPO Performance on China' Newest Stock Market (ChiNext)", The Chinese Economy, Vol. 48, pp. 87-113

Arik, E., and Mutlu E., (2015), "Post-Initial Public Offering Performance and Its Determinants: Initial Public Offering Characteristics and Corporate Governance Practices". Emerging Markets Finance and Trade, 51, pp. S62-S83

Chi, J., and Oadgett, C., (2006), "Operating Performance and Its Relationship to Market Performance of Chinese Initial Public Offerings", The Chinese Economy, 39 (5), pp. 28-50. doi.10.2743/CES1097-1475390502

Jain, B.A., and Kini, O. (1994), "The Post-Issue Operating Performance of IPO Firms", The Journal of Finance, 49, pp. 1699-1726

Jensen, M., and Mecking, H.M., (1976), "Theory of Firm: Managerial Behavior, Agency Costs and Ownership Structure". Journal of Financial Economics, 3(4) pp. 305360, doi.org/10.1016/0304-405X(76)90026-X

Kim, K.A., Kitsabunnarat, P., and Nofsinger, J.R., (2004), "Ownership and operating performance in an emerging market: evidence from Thai IPO firms". Journal of Corporate Finance, 10, pp. 355-381

Kutsuna, K., Okamura, H., Cowling, M., (2002), "Ownership structure pre- and post-IPOs and the operating performance of JASDAQ companies". Pacific-Basin Finance Journal, 10, pp. 163-181

Limpaphayom, P., and Ngamwutikul, A., (2004), “Ownership Structure and Post-Issue Operating Performance of Firms Conducting Seasoned Equity Offerings in Thailand", 28(3), pp. 307-332

McConaughy, L.D., Dhatt, S.M., Kim, H.Y., (1996), "Agency Costs, Market Discipline and Market Timing: Evidence from Post-IPO Operating Performance", 
Entrepreneurship Theory and Practice, 20(2), pp 43-57, doi.org/10.1177\%2F104225879602000205

SET Annual Report, Stock Exchange of Thailand (2014), https://www.set.or.th/en/about/annual/files/annual_report_2014_en.pdf SET Annual Report, Stock Exchange of Thailand (2017), https://www.set.or.th/en/about/annual/files/annual_report_2017_en.pdf

SME Promotion Master Plan, Office of SMEs Promotion (OSMEP) (2016), http://www.sme.go.th/th/index.php/about-osmep/promote/plan2

Xie, X., (2010), "Are publicly held firms less efficient? Evidence from the US propertyliability insurance industry", Journal of Banking \& Finance, Vol. 34, pp. 15491563 